\title{
ICP-OES Multi-element Analysis of Wheat Grown in Southeastern Turkey
}

\author{
M. Zahir Duz ${ }^{\mathrm{a} *}$, Mehmet Duzgun ${ }^{\mathrm{b}}$, Belgizar Cam ${ }^{\mathrm{b}}$, K. Serdar Celik ${ }^{\mathrm{c}}$, and Ersin Kilinç ${ }^{\mathrm{d} *}$ \\ ${ }^{a}$ Department of Chemistry, Science Faculty, University of Dicle, TR-21280 Diyarbakir, Turkey \\ ${ }^{b}$ Department of Quality and Technology, GAP International Agricultural Research and Training Centre, \\ Diyarbakir, Turkey \\ ${ }^{c}$ Department of Chemistry, Faculty of Arts and Sciences, Batman University, Batman, Turkey \\ d Mardin Artuklu University, Vocational Higher School of Healthcare Studies,
} TR-47000 Mardin, Turkey

\section{INTRODUCTION}

Cereals are an important source of nutrition and lack of micronutrients affects the health of all living things. The metabolism of all cells depends on a balanced diet containing carbohydrates, proteins, and lipids (1). Most of the trace elements come from daily intake of food, especially grains (2), which play important roles in different metabolic processes (3). In excess or a lack thereof may disturb the normal biochemical functions of the body (4). During the last decades, the demand for nutritional safety levels has stimulated research regarding the risks associated with the consumption of food and water contamination by trace metals or toxins (5). Some trace elements, such as $\mathrm{Cr}, \mathrm{Cu}, \mathrm{Ca}, \mathrm{Na}, \mathrm{K}, \mathrm{Fe}, \mathrm{Zn}, \mathrm{Mn}$, and Se, are essential for all life. In high concentrations, they can create toxicity in soil, humans, animals, and plants $(3,6)$. Trace elements, such as $\mathrm{Cd}$, $\mathrm{As}, \mathrm{Hg}$ and $\mathrm{Pb}$, are not essential but pose health risks when they enter the food and water chain $(7$, 8). Contaminants in nutrition typically do not lead to rapid mortality; however, they accumulate and cause chronic health effects (9). For example, $\mathrm{Pb}, \mathrm{Cd}, \mathrm{Hg}$, and $\mathrm{As}$ can cause acute and chronic poisoning of the liver, kidneys, heart, the vascular and immune systems (11). Iron and Ca are micronutrient elements that play an important role for hemoglobin formation, oxygen, electron transfer, teeth, the

*Corresponding authors.

E-mail: zabird@dicle.edu.tr (M.Z. Düz)

Tel:: +904122488001 (Ext. 3222)

E-mail: kilincersin@gmail.com (E. Kultnç)

Tel:: +9048221340 02 (Ext. 7284)

\section{ABSTRACT}

The bread and durum wheat varieties grown in Southeastern Turkey are the main source of food consumed by the Turkish population and serve as bread and pasta. In this study, 12 kinds of durum wheat and 5 kinds of bread wheat samples registered by the International Agricultural Research and Training Centre of Turkey (IARTC, Turkey) were investigated for their multi-elemental concentrations $(\mathrm{Ca}, \mathrm{K}$, $\mathrm{Mg}, \mathrm{Fe}, \mathrm{Zn}, \mathrm{Mn}, \mathrm{Si}, \mathrm{Sn}, \mathrm{Cu}, \mathrm{Cr}$, $\mathrm{Cd}, \mathrm{Ni}, \mathrm{V}, \mathrm{Pb}, \mathrm{As}$, and Se). The samples were microwavedigested and the elements determined by ICP-OES. The results were in good agreement with the certified values. This study shows that the elements $\mathrm{Si}, \mathrm{Fe}, \mathrm{Zn}, \mathrm{Cd}$, $\mathrm{Cr}, \mathrm{Cu}, \mathrm{Sn}$, and $\mathrm{Pb}$ in durum wheat were higher than in bread wheat. Both wheat species were found to be rich in terms of $\mathrm{Ca}$, $\mathrm{Mg}$, and $\mathrm{K}$. The multi-element content of some bread wheat and durum wheat was also in good agreement with the maximum allowable levels of the Food and Agriculture Organization (FAO) World Health (WHO).

muscular system, bones, and heart functions $(14,15)$. The elements $\mathrm{Zn}, \mathrm{Se}, \mathrm{Mg}$, and $\mathrm{Cu}$ are essential and support a wide range of biological functions including the enzymatic and redox systems (10).

In several studies $(12,13)$, wheat has been reported to show a substantial variation in trace element concentrations. Therefore, the concentration of microelements should be properly regulated through agro- nomic, biochemical, and physical processes by decontamination programs (16). The FAO/WHO report (17) states that it is the accountability of national authorities to guarantee that food, water, grain, and cereal products do not contain toxic chemical substances in concentrations that would affect the health status of humans. Table I lists some of the trace elements and their maximum allowable levels in air, food, and water, human intake per day of the metal, toxic quantities, and normal quantities in the body as approved by WHO (17) and the Turkish Standard Institution (18). In Turkey, the daily energy requirement of a person is met on average by an intake of $40 \%$ wheat products. Wheat is a carbohydrate that is ground into flour and is used for making bread and other products such as bulgur, pasta, biscuits, and many other food products (15).

According to a study by the International Agricultural Research and Training Centre (IARTC, Turkey), an increase in planting more wheat will result in an increase in the production of cereals and other foods and thus contribute to enhancing the economic development program for the provinces of Urfa, Diyarbakir, Gaziantep, Adiyaman, and Mardin (located in the basins of the Euphrates and the Tigris River in Upper Mesopotamia). The main purpose of the IARTC project is to help increase the standard of living of the farming community and all people involved in producing the cereals (wheat 34\%), barley, grains, and cotton. At present, these goals have been tripled due to irrigation 
from the Ataturk Dam. The farmers of the Harran plains feel very encouraged and also experiment by planting new varieties of fruits, vegetables, and nuts $(19,20)$.

The main objective of the present study was to investigate the variation in the micronutrient con- tent of a wide range of wheat grains used for bread and durum wheat products. The samples were obtained from different areas and include 12 kinds of durum wheat and 5 kinds of bread wheat. These samples were analyzed by using plasma-based spectrochemical tech-

TABLE I

Maximum Standard Elemental Values for Wheat and Daily Consumption Through Nutrient, Air, Food, and Water ${ }^{(3,17,18)}$

\begin{tabular}{|c|c|c|c|c|c|}
\hline $\begin{array}{l}\text { Ele- } \\
\text { ments }\end{array}$ & $\begin{array}{l}\text { Food and } \\
\text { Water } \\
\text { (m/g daily) }\end{array}$ & $\begin{array}{c}\text { Air } \\
\text { (m/g daily) }\end{array}$ & $\begin{array}{c}\text { Toxic } \\
\text { Effects } \\
\text { (m/g daily) }\end{array}$ & $\begin{array}{c}\text { Levels } \\
\text { in Body } \\
\text { (m/g daily) }\end{array}$ & $\begin{array}{l}\text { Max. Standard } \\
\text { Levels in Wheat } \\
(\mathrm{mg} / \mathrm{kg})\end{array}$ \\
\hline $\mathrm{Sb}$ & 1.000 & 0.0017 & 100 & 7.9 & NS \\
\hline $\mathrm{Cu}$ & 1.325 & 0.0014 & $250-500$ & 72.0 & $0.1-5.0$ \\
\hline $\mathrm{Ba}$ & 0.735 & 0.030 & 200 & 22 & 0.7 \\
\hline $\mathrm{Be}$ & 0.012 & 0.00004 & NS & 0.03 & NS \\
\hline $\mathrm{Bi}$ & 0.020 & 0.00076 & NS & 0.23 & NS \\
\hline $\mathrm{Hg}$ & 0.0025 & NS & NS & NS & 0.006 \\
\hline $\mathrm{Zn}$ & 14.500 & 0.0168 & NS & 2300 & 20 \\
\hline $\mathrm{Fe}$ & 15.000 & 0.084 & NS & 4200 & $1.5-20$ \\
\hline Ag & 0.600 & NS & 60 & 1.0 & NS \\
\hline $\mathrm{Cd}$ & 0.016 & 0.0074 & 3 & 50 & 0.005 \\
\hline Sn & 7.300 & 0.0006 & 2000 & 17 & $150-250$ \\
\hline $\mathrm{Co}$ & 0.390 & 0.00012 & 500 & 1.5 & NS \\
\hline $\mathrm{Pb}$ & 0.300 & 0.046 & NS & 12.0 & $0.1-2.0$ \\
\hline $\mathrm{Cr}$ & 0.245 & 0.0011 & 200 & 1.8 & NS \\
\hline Mn & 4.400 & 0.0288 & NS & 12 & 0.2 \\
\hline Мо & 0.335 & 0.006 & NS & 9.3 & NS \\
\hline $\mathrm{Ni}$ & 0.600 & 0.00236 & NS & 10 & NS \\
\hline $\mathrm{Ti}$ & 1.375 & 0.0014 & NS & 9 & NS \\
\hline $\mathrm{U}$ & 0.050 & NS & NS & 0.7 & NS \\
\hline V & 0.116 & 0.00916 & NS & 22 & NS \\
\hline $\mathrm{Zr}$ & 0.490 & NS & NS & 420 & NS \\
\hline
\end{tabular}

NS : Indicates that no standard exists.

TABLE II

Instrumental Operating Conditions Using Model ICAP 6300 ICP-OES

\begin{tabular}{lll}
\hline Parameters & Normal & Hydride System \\
\hline Power & $1150 \mathrm{~W}$ & $1350 \mathrm{~W}$ \\
Pump Speed & $50 \mathrm{rpm}$ & $30 \mathrm{rpm}$ \\
Purge Gas & Argon & Argon \\
Coolant Gas Flow & $12 \mathrm{~L} / \mathrm{min}$ & $16 \mathrm{~L} / \mathrm{min}$ \\
Auxiliary Gas Flow & $0.5 \mathrm{~L} / \mathrm{min}$ & $0.5 \mathrm{~L} / \mathrm{min}$ \\
Torch & Axial, Radial & Axial \\
Autosampler & Cetac ASX-260 & \\
\hline
\end{tabular}

niques to assess whether these grains contain toxic levels of trace elements.

\section{EXPERIMENTAL}

\section{Instrumentation}

For this study, a model ICAPTM 6300 inductively coupled plasma optical emission spectrometer (ICPOES) (Thermo Fisher Scientific, USA) was used to determine the elements in bread and durum wheat varieties. The most sensitive lines without spectral interferences in the sample matrix were used for the analysis (21). The instrumental and operating parameters are listed in Table II.

\section{Standard Solutions and Reagents}

The standard solutions and their elemental concentrations were in the range of $50-400 \mathrm{mg} / \mathrm{L}$ for $\mathrm{Ca}$, $\mathrm{Na}, \mathrm{K}$, and $\mathrm{Mg} ; 2.5-40 \mathrm{mg} / \mathrm{L}$ for $\mathrm{Fe}$, $\mathrm{Zn}, \mathrm{Mn}, \mathrm{Ni}, \mathrm{Sn}, \mathrm{Cd}, \mathrm{Cr}, \mathrm{Cu}$, and $\mathrm{Pb}$; and $0.05-1.0 \mathrm{mg} / \mathrm{L}$ for $\mathrm{V}$. They were prepared by diluting an ICP multi-element stock solution at 1000 mg/L (High-purity Standards, Charleston, SC, USA). Arsenic and selenium were studied by using a hydride system (Thermo Fisher Scientific, Waltham, MA, USA) mounted on the ICP-OES. The As and Se standard solutions (10, 20, 40,60 , and $100 \mu \mathrm{g} / \mathrm{L}$ ) were prepared by adding a 1.0-mL mixture of ascorbic acid and KI (by dissolving $5.0 \mathrm{~g}$ ascorbic acid and $5.0 \mathrm{~g}$ of $\mathrm{KI}$ in $100 \mathrm{~mL}$ ultrapure water), then diluting with $10 \% \mathrm{HCl}$. The same procedure was applied to the wheat samples. The concentration of each element was calculated using calibration curves that were prepared from the standard solutions. The standard curves were found to be linear with a correlation coefficient of 0.999 .

The limit of detection (LOD) and limit of quantification (LOQ) for each element were determined by using analytical curves performed 
with 10 independent analyses of a blank solution spiked with the metal at a level of lower concentration. The LOD and LOQ were calculated from the standard deviation $(\alpha)$ of the determinations $($ LOD $=$ $3 \times \alpha$ and LOQ $=10 \times \alpha$ ), and the analytical results are listed in Table III.

\section{Samples and Sample Preparation}

In this study, 12 durum wheat and 5 bread wheat samples were obtained from the Department of Field Grain, located near the Tigris
River, registered by IARTC. The types and names of the different durum wheat samples used were Güney Yildizi, Zühre Eyyubi, Artuklu, Sahinbey, Saricnak-98, Altintoprak-98, Firat-93, Aydin-93, Harran-95, Ceylan-95, and Diyarbakir- 81 . The bread wheat samples were Karacadag-98, Aday-13, Nurkent, Dinç, and Cemre. In order to preserve the original quality of the wheat, the samples were stored at ambient temperature in sealed plastic bags prior to any conditioning. The wheat samples were washed with

TABLE III

Detection and Quantification Limits of Elemental Analytical Wavelengths

\begin{tabular}{llcc}
\hline Elements & $\begin{array}{c}\text { Wavelength } \\
(\mathrm{nm})\end{array}$ & $\begin{array}{c}\text { LOD } \\
(\mathrm{mg} / \mathrm{kg})\end{array}$ & $\begin{array}{c}\text { LOQ } \\
(\mathrm{mg} / \mathrm{kg})\end{array}$ \\
\hline $\mathrm{Ca}$ & $(317.933)$ & 0.031 & 0.103 \\
$\mathrm{~K}$ & $(766,440)$ & 0.040 & 0.133 \\
$\mathrm{Mg}$ & $(279.553)$ & 0.009 & 0.028 \\
$\mathrm{Fe}$ & $(259.940)$ & 0.220 & 0.733 \\
$\mathrm{Zn}$ & $(213.856)$ & 0.003 & 0.010 \\
$\mathrm{Sn}$ & $(189.989)$ & 0.093 & 0.310 \\
$\mathrm{Mn}$ & $(257.610)$ & 0.018 & 0.060 \\
$\mathrm{Cr}$ & $(205.560)$ & 0.002 & 0.007 \\
$\mathrm{Cu}$ & $(224.754)$ & 0.001 & 0.005 \\
$\mathrm{Cd}$ & $(214.438)$ & 0.001 & 0.005 \\
$\mathrm{Si}$ & $(251.611)$ & 0.046 & 0.153 \\
$\mathrm{Ni}$ & $(221.647)$ & 0.002 & 0.008 \\
$\mathrm{~V}$ & $(292.402)$ & 0.002 & 0.006 \\
$\mathrm{~Pb}$ & $(220.353)$ & 0.002 & 0.008 \\
$\mathrm{As}$ & $(189.042)$ & 0.020 & 0.066 \\
$\mathrm{Se}$ & $(196.090)$ & 0.004 & 0.015 \\
\hline
\end{tabular}

LOQ: Limit of quantification.

LOD: Limit of detection.

TABLE IV

Temperature Program of Microwave Digestion System for Wheat Samples

\begin{tabular}{lrrrr}
\hline Step & 1 & 2 & \multicolumn{1}{c}{3} & \multicolumn{1}{c}{4} \\
\hline $\mathrm{T}\left({ }^{\circ} \mathrm{C}\right)$ & 160 & 170 & 100 & 100 \\
$\mathrm{~T}(\mathrm{~min})^{\mathrm{a}}$ & 10 & 5 & 1 & 1 \\
Time $(\min )^{\mathrm{b}}$ & 15 & 10 & 10 & 0 \\
\hline
\end{tabular}

\footnotetext{
${ }^{a}$ Waiting time at desired temperature.

b Time between the two sequential temperatures.
}

\section{Atomic Spectroscopy \\ 1 Vol. 38(1), Jan./Feb. 2017}

pure water in a beaker in order to separate the impurities. The samples were dried in an oven at $70^{\circ} \mathrm{C}$ for 24 hours, then ground to 300 mesh with a flour mill (Lab Mill 3100, Perten Hägersten, Sweden). An amount of $0.25 \mathrm{~g}$ of the dried and ground wheat samples was accurately weighed into the digestion vessels, and $10 \mathrm{~mL}$ of $65 \%$ $\mathrm{HNO}_{3}$ and $2 \mathrm{~mL}$ of $30 \% \mathrm{H}_{2} \mathrm{O}_{2}$ were added. The vessels were closed and heated in a MWS-3 Berghof microwave oven (Berghof, Germany) as listed in Table IV.

The vessels were removed and vented in a fume hood after cooling to room temperature in a water bath. The reaction mixture was subjected to an evaporation procedure by using the evaporation module to remove the acids after digestion. Then, the samples were filtered and diluted to $25 \mathrm{~mL}$ with Milli-Q ${ }^{\circledR}$ ultrapure water (Millipore Corporation, USA).

\section{Accuracy of the Method}

The certified standard reference material (CRM) GBW 10010 Wheat (General Administration of Quality Supervision, Langfang, P.R. China) was used to assess the accuracy and precision of the method. The CRM sample was analyzed in triplicate by ICP-OES. The results were in good agreement with the certified values and are listed in Table V.

\section{RESULTS AND DISCUSSION}

In this study, the concentrations of $\mathrm{Ca}, \mathrm{K}, \mathrm{Mg}, \mathrm{Fe}, \mathrm{Zn}, \mathrm{Mn}, \mathrm{Si}, \mathrm{Sn}, \mathrm{Cu}$, $\mathrm{Cr}, \mathrm{Cd}, \mathrm{Ni}, \mathrm{V}, \mathrm{Pb}, \mathrm{As}$, and Se in 12 kinds of durum wheat and 5 kinds of bread wheat samples were analyzed. The wheat samples were acid-digested in the microwave digestion system (Table II). The procedure used for the sample preparation and digestion of the plant matrices was performed by adding $10 \mathrm{~mL}$ of $\mathrm{H}_{2} \mathrm{O}_{2}$ to $\mathrm{HNO}_{3}$. This increases the oxidation power of $\mathrm{HNO}_{3}$ during the digestion and 
enhances the dissolution of the organic material present in the sample before ICP-OES measurements (22-25).

The limit of detection (LOD) and the limit of quantification (LOQ) for each element were determined. The detection limits were within acceptable limits for all elements except As which was $<0.002$ $\mathrm{mg} / \mathrm{kg}$ (Table III). A certified reference material was used in order to verify the accuracy of the method. The results obtained from the study were in good agreement with the certified values (Table V).

The results of the analyses listed in Table VI were compared with the values as provided by the Turkish Standard Institution (18), WHO (17), and other studies (Table I).

\section{Calcium (Ca)}

The values of Ca were found to be $480 \pm 6$ to $742 \pm 20 \mathrm{mg} / \mathrm{kg}$ in the durum wheat sample and $420 \pm 4$ to $625 \pm 54 \mathrm{mg} / \mathrm{kg}$ in the bread wheat sample (Table VI). According to Ereifej et al. (26), the Ca values in durum wheat from Jordan, Morocco, and the FAO were found as $29.5 \pm 0.6,40.1 \pm 0.5$ and 55.8 $\mathrm{mg} / 100 \mathrm{~g}$, respectively. Hongxing and Kui (2012) (27) reported the Ca values as $200.63 \mu \mathrm{g} / \mathrm{g}$, which is lower than those obtained in the present study.

\section{Magnesium (Mg)}

The Mg values found were between $526 \pm 62$ and $856 \pm 14$ $\mathrm{mg} / \mathrm{kg}$ in durum wheat and from $762 \pm 8$ to $883 \pm 23 \mathrm{mg} / \mathrm{kg}$ in bread wheat, which indicates that the $\mathrm{Mg}$ concentrations were higher in bread wheat. Ereifej et al. (26) reported $\mathrm{Mg}$ values in Jordanian and Moroccan durum wheat as $85.1 \pm 4$ and $137 \pm 2 \mathrm{mg} / 100 \mathrm{~g}$, respectively. According to Hongxing and Kui (27), the Mg value was $321.11 \mu \mathrm{g} / \mathrm{g}$ for Peking wheat. It can be seen that the Mg concentration determined in this study is higher than those in the literature.

TABLE V

Accuracy Assessment of Analysis of CRM GBW 10010 Wheat ( $n=3$, dry weight)

\begin{tabular}{lllr}
\hline Elements & $\begin{array}{c}\text { CRM } \\
(\mathrm{mg} / \mathrm{kg})\end{array}$ & $\begin{array}{c}\text { Found } \\
(\mathrm{mg} / \mathrm{kg})\end{array}$ & $\begin{array}{c}\text { Recovery } \\
(\%)\end{array}$ \\
\hline $\mathrm{Ca}$ & $340 \pm 20$ & $348 \pm 16$ & 102 \\
$\mathrm{Mg}$ & $450 \pm 25$ & $437 \pm 32$ & 97 \\
$\mathrm{~K}$ & $1400 \pm 60$ & $1370 \pm 78$ & 94 \\
$\mathrm{Si}$ & $80 \pm 4.15$ & $92 \pm 4.31$ & 97 \\
$\mathrm{Fe}$ & $18.5 \pm 3.1$ & $17.4 \pm 3.8$ & 94 \\
$\mathrm{Zn}$ & $11.6 \pm 0.70$ & $11.8 \pm 0.74$ & 102 \\
$\mathrm{Mn}$ & $5.4 \pm 0.30$ & $5.5 \pm 0.42$ & 102 \\
$\mathrm{Ni}$ & $0.060 \pm 0.02$ & $0.062 \pm 0.03$ & 103 \\
$\mathrm{Cd}$ & $0.180 \pm 0.04$ & $0.185 \pm 0.05$ & 102 \\
$\mathrm{Cr}$ & $0.096 \pm 0.013$ & $0.092 \pm 0.020$ & 96 \\
$\mathrm{Cu}$ & $2.70 \pm 0.20$ & $2.65 \pm 0.18$ & 98 \\
$\mathrm{~Pb}$ & $0.065 \pm 0.024$ & $0.066 \pm 0.027$ & 101 \\
$\mathrm{~V}$ & $0.034 \pm 0.012$ & $0.035 \pm 0.014$ & 103 \\
$\mathrm{As}$ & $0.031 \pm 0.005$ & $0.030 \pm 0.006$ & 97 \\
$\mathrm{Se}$ & $0.053 \pm 0.007$ & $0.054 \pm 0.009$ & 102 \\
\hline
\end{tabular}

$\mathrm{n}=$ replicate .

\section{Potassium (K)}

The $\mathrm{K}$ values were found to be between $1988 \pm 52$ and $2868 \pm 100$ $\mathrm{mg} / \mathrm{kg}$ in durum wheat and between $1896 \pm 70$ and $2954 \pm 13$ $\mathrm{mg} / \mathrm{kg}$ in bread wheat. These values are higher than those of the Peking wheat $(1569.34 \mathrm{mg} / \mathrm{kg})$ as reported by Hongxing and Kui (27).

\section{Iron $(\mathrm{Fe})$}

The Fe values were determined to be between $41.0 \pm 0.2$ and $57 \pm 0.2$ $\mathrm{mg} / \mathrm{kg}$ in durum wheat and between $34.7 \pm 0.25$ and $47.6 \pm 5$ $\mathrm{mg} / \mathrm{kg}$ in bread wheat. Al-Gahri et al. (28) reported values of $51.06 \pm 0.13,57.63 \pm 0.12$, and 60.54 $\pm 0.09 \mu \mathrm{g} / \mathrm{g}$, respectively, for wheat grain samples grown in Yemen, Austria, and the U.S.

\section{Zinc (Zn)}

The $\mathrm{Zn}$ values obtained were between $18.8 \pm 0.2$ to $34.8 \pm 0.2$ $\mathrm{mg} / \mathrm{kg}$ in durum wheat and $18.4 \pm 0.09$ to $27.1 \pm 1.7 \mathrm{mg} / \mathrm{kg}$ in bread wheat. According to Al-Gahri at al. (28), the $\mathrm{Zn}$ values in wheat from Yemen, Austria, and the U.S. were found to be $16.96 \pm 0.09$, $11.55 \pm 0.13$, and $17.13 \pm 0.12 \mu \mathrm{g} / \mathrm{g}$, respectively, for wheat grain samples, and was lower than those found in the present study.

\section{Silicon (Si)}

The Si values obtained were in the range of $41.4 \pm 2$ to $97.5 \pm 1.3$ $\mathrm{mg} / \mathrm{kg}$ in the durum wheat and $34.2 \pm 0.7$ to $65.5 \pm 4 \mathrm{mg} / \mathrm{kg}$ in the bread wheat.

\section{Manganese (Mn)}

The Mn values obtained were between $33.2 \pm 0.6$ and $50.5 \pm 0.04$ $\mathrm{mg} / \mathrm{kg}$ in durum wheat and $34.1 \pm 1$ to $45.3 \pm 0.9 \mathrm{mg} / \mathrm{kg}$ in bread wheat. No significant difference was found between the results of the present study and those reported by AlGahri et al. (28) and Ereifej et al. (26). In the Peking wheat, the Mn value was reported as $6.69 \mu \mathrm{g} / \mathrm{g}$ (27). 


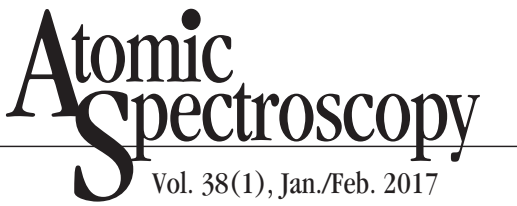

TABLE VI

Trace Element Concentrations in Durum Wheat and Bread Wheat (mean \pm S.D, $\mathbf{n}=3)(\mathrm{mg} / \mathrm{kg}$, dry weight)

\begin{tabular}{|c|c|c|c|c|c|c|c|c|}
\hline Samples & $\mathrm{Ca}$ & $\mathrm{Mg}$ & $\mathrm{K}$ & $\mathrm{Fe}$ & $\mathrm{Si}$ & $\mathrm{Mn}$ & $\mathrm{Zn}$ & Sn \\
\hline \multicolumn{9}{|l|}{ Durum Wheat } \\
\hline Güneyyildizi & $629^{a} \pm 27^{b}$ & $766 \pm 25$ & $2537 \pm 86$ & $44.4 \pm 6$ & $46.1 \pm 4.7$ & $35.5 \pm 10$ & $29.4 \pm 0.06$ & $30.0 \pm 10$ \\
\hline Zühre & $595 \pm 12$ & $784 \pm 15$ & $2580 \pm 51$ & $57 \pm 0.2$ & $72.5 \pm 0.8$ & $35.7 \pm 0.6$ & $23.83 \pm 0.2$ & $31.4 \pm 10$ \\
\hline Eyyubi & $605 \pm 5$ & $526 \pm 62$ & $2405 \pm 14$ & $49.2 \pm 1$ & $44.3 \pm 2.2$ & $33.3 \pm 3$ & $26.6 \pm 0.08$ & $22.4 \pm 7$ \\
\hline Artuklu & $681 \pm 64$ & $851 \pm 20$ & $2703 \pm 58$ & $48.3 \pm 5$ & $62.3 \pm 5$ & $42.7 \pm 5$ & $33.4 \pm 4.0$ & $23.1 \pm 4$ \\
\hline Sahinbey & $624 \pm 2.4$ & $843 \pm 9.5$ & $2741 \pm 38$ & $50 \pm .0 .7$ & $97.5 \pm 1.3$ & $46.9 \pm 0.6$ & $34.8 \pm 0.2$ & $13.4 \pm 0.8$ \\
\hline Sariçanak-98 & $704 \pm 11$ & $856 \pm 14$ & $2868 \pm 86$ & $52.1 \pm 5$ & $55.4 \pm 19$ & $48.2 \pm 4$ & $31.2 \pm 0.1$ & $23.1 \pm 4$ \\
\hline Altintoprak-98 & $670 \pm 2.6$ & $789 \pm 11$ & $2506 \pm 59$ & $72.8 \pm 0.3$ & $55.0 \pm 0.4$ & $50.5 \pm 0.04$ & $32.7 \pm 0.1$ & $27 \pm 1.5$ \\
\hline Firat-93 & $480 \pm 6$ & $828 \pm 9$ & $2486 \pm 24$ & $49.2 \pm 4$ & $78.3 \pm 8$ & $43.5 \pm 3$ & $21.6 \pm 0.1$ & $33.9 \pm 13$ \\
\hline Aydin-93 & $742 \pm 20$ & $819 \pm 15$ & $2626 \pm 32$ & $41.0 \pm 0.2$ & $49 \pm 13$ & $43.5 \pm 7.3$ & $29.3 \pm 0.2$ & $15.7 \pm 1.7$ \\
\hline Harran-95 & $652 \pm 17$ & $740 \pm 82$ & $2695 \pm 102$ & $43.1 \pm 0.9$ & $49.3 \pm 3$ & $33.2 \pm 0.6$ & $23.5 \pm 0.2$ & $16.5 \pm 4$ \\
\hline Ceylan-95 & $720 \pm 26$ & $587 \pm 41$ & $1988 \pm 52$ & $50.3 \pm 1.8$ & $41.4 \pm 2$ & $42.1 \pm 1.56$ & $23.0 \pm 0.08$ & $15.6 \pm 3.3$ \\
\hline Diyarbakir-81 & $718 \pm 8$ & $829 \pm 7.5$ & $2752 \pm 38$ & $44.2 \pm 0.6$ & $85.5 \pm 1.3$ & $44.2 \pm 0.6$ & $18.8 \pm 0.2$ & $13.1 \pm 0.8$ \\
\hline Ref. (26) & $29.5-40.1$ & $85.1 \pm 4$ & & & & & & \\
\hline Ref. (27) & 200.63 & 321.11 & 1569.34 & & & & & \\
\hline Ref. (28) & & & & $51.06-60.54$ & & & $11.55-17.13$ & \\
\hline \multicolumn{9}{|l|}{ Bread Wheat } \\
\hline Cemre & $487 \pm 11$ & $883 \pm 23$ & $2514 \pm 121$ & $47.6 \pm 5$ & $56.4 \pm 5$ & $41.5 \pm 1$ & $20.7 \pm 0.1$ & $21.2 \pm 2$ \\
\hline Nurkent & $625 \pm 54$ & $842 \pm 3$ & $2954 \pm 13$ & $44.1 \pm 7$ & $65.5 \pm 4$ & $42.7 \pm 5.2$ & $27.1 \pm 1.7$ & $20.3 \pm 3.9$ \\
\hline Karacadag-98 & $454 \pm 11$ & $856 \pm 21$ & $2504 \pm 16$ & $43.3 \pm 1$ & $34.3 \pm 3$ & $45.3 \pm 0.9$ & $26.4 \pm 0.05$ & $15.4 \pm 1.7$ \\
\hline Dinç & $420 \pm 4$ & $762 \pm 8$ & $1974 \pm 10$ & $38.2 \pm 4$ & $44.8 \pm 2$ & $39.4 \pm 3$ & $18.4 \pm 0.09$ & $16.2 \pm 1.6$ \\
\hline Aday-13 & $495 \pm 7$ & $778 \pm 20$ & $1896 \pm 70$ & $34.7 \pm 0.25$ & $34.2 \pm 0.7$ & $34.1 \pm 1$ & $19.2 \pm 0.09$ & $13.6 \pm 1$ \\
\hline
\end{tabular}

${ }^{a}=\operatorname{mean}^{\mathrm{b}}=\mathrm{sd}$

Table VI cont'd. on next page

\section{Mean Elemental Composition of Samples}

A study of the mean elemental composition of the durum wheat and the bread wheat samples showed that the $\mathrm{Ca}, \mathrm{Mg}$, and $\mathrm{K}$ values were the most abundant elemental species. The $\mathrm{Pb}$ values were higher in durum wheat, whereas the $\mathrm{V}$ values were higher in bread wheat. The concentration of Si was higher in both wheat products because of the high amount of silica content in the soil. However, based on the WHO and Turkish standards, the $\mathrm{Mg}, \mathrm{Ca}, \mathrm{K}, \mathrm{Pb}, \mathrm{V}$, and Si values were not at toxic levels. The concentrations of metal ions found in the present study and those reported in the literature show no significant differences.

\section{CONCLUSION}

This study revealed that the concentrations of $\mathrm{Ca}, \mathrm{Si}, \mathrm{Fe}, \mathrm{Zn}, \mathrm{Cd}, \mathrm{Cr}$, $\mathrm{Cu}, \mathrm{Sn}$, and $\mathrm{Pb}$ in durum wheat were generally higher than in bread wheat. In general, the metal concentrations determined follows the order of $\mathrm{K}>\mathrm{Mg}>\mathrm{Ca}>\mathrm{Fe}>\mathrm{Si}>$ $\mathrm{Mn}>\mathrm{Zn}>\mathrm{Sn}>\mathrm{Cu}>\mathrm{Cr}>\mathrm{Ni}>\mathrm{Pb}$ $>\mathrm{Se}>\mathrm{V}>\mathrm{Cd}>$ As. Based on the allowable limits established by FAO/WHO and the Turkish Food Codex, all of these elements studied are not present at toxic levels. The results of this study also show that the wheat grains grown in Turkey contain non-toxic mineral concentrations. These grains are mostly used for food and food products, are very important for human nutrition, and thus make it an unpolluted and safe source of nutrition.
Received December 4, 2015.

Revision received October 12, 2016.

\section{REFERENCES}

1. Y. Lin, Y. Ho, Y. Zhao and Y. Chang, J. Food Drug Anal. 23, 130 (2015).

2. H. Gokbel, M. Harmankaya and M.M. Ozcan, Quality Assurance and Safety of Crops \& Foods 7, 545 (2015).

3.WHO, Trace elements in human nutrition and health. Geneva, Switzerland, pp. 361 (1996).

4. L.A.A. Soriano-Melgara, L. AlcarazMelendezb, L.C. Mendez-Rodrigueza, M.E. Puentea, F. RiveraCabrerac and T. Zenteno-Savin, Ind. Crop Prod. 37, 321 (2012).

5. J.P.F. D'Mello, Food safety: contaminants and toxins. CABI Publishing, 
TABLE VI (continued)

Trace Element Concentrations in Durum Wheat and Bread Wheat (mean \pm S.D, $\mathrm{n}=3)(\mathrm{mg} / \mathrm{kg}$, dry weight)

\begin{tabular}{|c|c|c|c|c|c|c|c|c|}
\hline & $\mathrm{Cu}$ & $\mathrm{Cd}$ & $\mathrm{Cr}$ & $\mathrm{Ni}$ & $\mathrm{V}$ & $\mathrm{Pb}$ & As & Se \\
\hline \multicolumn{9}{|l|}{ Durum Wheat } \\
\hline Güneyyildizi & $7.75 \pm 2.0$ & $0.041 \pm 0.003$ & $0.82 \pm 0.25$ & $0.72 \pm 0.009$ & $0.042 \pm 0.01$ & $0.210 \pm 0.01$ & $<0.002$ & $0.312 \pm 0.01$ \\
\hline Zühre & $4.22 \pm 0.02$ & $0.011 \pm 0.002$ & $1.41 \pm 0.02$ & $0.62 \pm 0.007$ & $0.090 \pm 0.02$ & $0.171 \pm 0.05$ & $<0.002$ & $0.250 \pm 0.08$ \\
\hline Eyyubi & $10.5 \pm 0.3$ & $0.042 \pm 0.001$ & $1.03 \pm 0.02$ & $0.93 \pm 0.03$ & $0.091 \pm 0.01$ & $0.242 \pm 0.08$ & $<0.002$ & $0.260 \pm 0.11$ \\
\hline Artuklu & $10.5 \pm 0.3$ & $0.042 \pm 0.001$ & $1.03 \pm 0.02$ & $0.93 \pm 0.03$ & $0.091 \pm 0.01$ & $0.242 \pm 0.08$ & $<0.002$ & $0.260 \pm 0.11$ \\
\hline Sahinbey & $7.83 \pm 1.5$ & $0.010 \pm 0.001$ & $0.12 \pm 0.01$ & $0.85 \pm 0.008$ & $0.062 \pm 0.02$ & $0.163 \pm 001$ & $<0.002$ & $0.374 \pm 0.06$ \\
\hline Sariçanak-98 & $5.11 \pm 2.0$ & $0.006 \pm 0.002$ & $1.02 \pm 0.04$ & $0.11 \pm 0.03$ & $0.072 \pm 0.01$ & $0.111 \pm 0.0$ & $<0.002$ & $0.337 \pm 0.09$ \\
\hline Altintoprak-98 & $7.15 \pm 0.02$ & $0.014 \pm 0.003$ & $1.05 \pm 0.01$ & $0.98 \pm 0.02$ & $0.04 \pm 0.009$ & $0.124 \pm 0.09$ & $<0.002$ & $0.344 \pm 0.11$ \\
\hline Firat-93 & $5.20 \pm 0.4$ & $0.052 \pm 0.005$ & $1.21 \pm 0.02$ & $0.89 \pm 0.009$ & $0.060 \pm 0.01$ & $0.162 \pm 0.01$ & $<0.002$ & $0.293 \pm 0.06$ \\
\hline Aydin-93 & $8.70 \pm 1.2$ & $0.021 \pm 0.003$ & $0.85 \pm 0.00$ & $0.71 \pm 0.005$ & $0.040 \pm 0.01$ & $0.181 \pm 0.02$ & $<0.002$ & $0.385 \pm 0.03$ \\
\hline Harran-95 & $13.2 \pm 0.2$ & $0.030 \pm 0.003$ & $1.08 \pm 0.02$ & $0.72 \pm 0.01$ & $0.102 \pm 0.02$ & $0.160 \pm 0.06$ & $<0.002$ & $0.400 \pm 0.03$ \\
\hline Ceylan-95 & $14.7 \pm 0.6$ & $0.061 \pm 0.0005$ & $1.42 \pm 0.04$ & $0.72 \pm 0.04$ & $0.09 \pm 0.008$ & $0.220 \pm 0.03$ & $<0.002$ & $0.312 \pm 0.08$ \\
\hline Diyarbakir-81 & $4.91 \pm 0.1$ & $0.060 \pm 0.001$ & $1.63 \pm 0.01$ & $0.54 \pm 0.01$ & $0.05 \pm 0.006$ & $0.091 \pm 0.01$ & $<0.002$ & $0.398 \pm 0.05$ \\
\hline \multicolumn{9}{|l|}{ Bread Wheat } \\
\hline Cemre & $6.2 \pm 1$ & $0.011 \pm 0.001$ & $0.81 \pm 0.01$ & $0.9 \pm 0.02$ & $1.483 \pm 0.1$ & $<0.0025$ & $<0.002$ & $0.324 \pm 0.02$ \\
\hline Nurkent & $5.5 \pm 0.9$ & $0.002 \pm 0.0004$ & $0.52 \pm 0.03$ & $0.78 \pm 0.07$ & $0.051 \pm 0.02$ & $0.041 \pm 0.01$ & & \\
\hline Karacadag-98 & $5.2 \pm 0.1$ & $0.021 \pm 0.003$ & $0.66 \pm 0.05$ & $0.72 \pm 0.02$ & $1.212 \pm 0.10$ & $<0.0025$ & $<0.002$ & $0.322 \pm 0.07$ \\
\hline Dinç & $4.4 \pm 0.1$ & $0.008 \pm 0.0005$ & $0.97 \pm 0.01$ & $0.56 \pm 0.01$ & $1.041 \pm 0.34$ & $0.022 \pm 0.001$ & $<0.002$ & $0.350 \pm 0.04$ \\
\hline Aday-13 & $4.4 \pm 0.1$ & $0.032 \pm 0.003$ & $0.52 \pm 0.009$ & $0.57 \pm 0.03$ & $1.351 \pm 0.11$ & $0.044 \pm 0.01$ & $<0.002$ & $0.344 \pm 0.06$ \\
\hline
\end{tabular}

Wallingford/Oxon/Cambridge, England, pp. 480 (2003).

6. M.J. Hawkesford and F.J. Zhao, J. Cereal Sci. 46, 282 (2007).

7. Z.H. Liu, H.Y. Wang, X.E. Wang, G.P. Zhang, P.D. Chen and D.J. Liu, J. Cereal Sci. 44, 212 (2006).

8. Z.H. Liu, H.Y. Wang, X.E. Wang, G.P. Zhang, P.D. Chen and D.J. Liu, J. Cereal Sci. 45, 319 (2007).

9. B. Nedjimiand and Y. Daoud, Flora 204, 316 (2009).

10. R.B. Heyes, Cancer Causes Control 8, 371 (1997).

11.I. Kaya and N. Incekara, J. Turk. Weed Sci. 3, 56 (2000).

12. Anonymous, 2008, World Food Supply. T. Brody, Nutritional Biochemistry, San Diego, CA, USA: Academic Press (1994).

13. M.J. McLaughlin, D.R. Parkerand J.M. Clarke, Field Crop. Res. 60, 143 (1999).

14. F.J. Zhao, F.J. Lopez-Bellido, C.W. Gray, W.R. Whalley, L.J. Clark and
S.P. McGrath, Sci. Total Environ. 372, 433 (2006).

15. F.J. Zhao, Y.H. Su, S.J. Dunham, M Rakszegi, Z. Bedo, S.P. McGrath and P.R. Shewry, Cereal Sci. 49, 290 (2009).

16. B.R. Singh, S.K. Gupta, H.Azaizeh, S.Shilev, D.Sudre, W.Y. Song, E.Martinoia and M. Mench, J. Sci. Food Agric. 91, 1349 (2011).

17. WHO, Evaluation of certain food additives and contaminants (41st Report of the Joint FAO/WHO Expert Committee on Food Additives), WHO Technical Report Series, No. 837. Geneva, Switzerland (1993).

18 .Turkish Standard Institution, TS266/T1 2014, Water intended for human consumption.

19. IHO Unversity Southeastern Anatolia Project GAP. Water Research Development 1997a; 13-4:453-484.

20. K. Kaygusuz, Energ. Source Part B 5, 199 (2010).
21. O. Akba, E. Kilinc, I. Aydın, S. Erdogan, F. Aydin, M.Z.Duz and C. Hamamci, At. Spectrosc. 32, 48 (2013).

22. M.Z. Duz, K.S.Celik, I. Aydin, S. Erdogan and F. Aydin, At. Spectrosc.33, 78 (2012).

23. K.S. Celik, F. Aydin, M.Z. Duz, I. Aydin, S. Erdogan, O. Akbaand C. Hamamci, At. Spectrosc. 35, 200 (2014).

24. B. Gumgum and C. Hamamci, Spectrosc. Lett. 24, 1229 (1991).

25. M. Merdivan, E. Yilmaz, C. Hamamci and R.S. Aygun, Food Chem. 87, 163 (2004).

26. K.I. Ereifej and S.G. Haddad, Trends Food Sci.Tech.11, 374 (2000).

27. S. Hongxing and R.Y. Kui, J. Saudi Chem. Soc. 16, 31 (2012).

28. M.A. Al-Gahri and M.A. AlMussali, E-Journal of Chem. 5, 838 (2008). 